УДК 78.01/782.1

\title{
Ван Пен
}

\section{ДРАМАТИЧЕСКАЯ УСЛОВНОСТЬ ОПЕРНОГО ХАРАКТЕРА В СВЕТЕ ДИАЛОГИЧЕСКОГО ПОДХОДА: К ПОСТАНОВКЕ ПРОБЛЕМЫ}

В статье разрабатывается дефиниция драматического оперного характера, определяются драматические аспекты оперного образа как предпосылка воплощения оперного характера. Предлагаются диалогические критерии оценки сценического поведения оперных персонажей, уточняются разновидности катартического разрешения драматических оперных коллизий. Ставится вопрос о необходимости драматического углубления профессионального мастерства оперных певцов.

Ключевые слова: драматический характер, оперное исполнение, диалог, игра, катарсис.

Применение наиболее общих понятий, можно сказать, универсалий гуманитарного знания, таких как индивидуальность - личность - характер, к типологии оперных образов и творческой практики оперных певцов является особой теоретической задачей, интердисциплинарное положение и значение которой определяется сложно-синтетической природой оперного искусства, в том числе и как искусства театрально-драматического.

Современное представление о сценических ролевых функциях оперного исполнителя свидетельствует о возрождении первой и основной, фундаментальной «памяти жанра», актуализации первичных как внешних ситуативно-прикладных, так и внутренних эстетических обязательств оперного творчества. На современном витке эволюции опера, пусть и индивидуально-авторскими композиторскими и режиссерскими усилиями, стремится вернуться к своей театрально-видовой сущности и в этом музыкально-творческом «дежавю» обновить игровую природу жанра. Вследствие этого ключевым моментом в создании образа оперного персонажа, как единицы оперного действия, становится определение и представление драматического характера.

Цель данной статьи - определить круг методических вопросов, позволяющий развивать дефиницию оперного драматического характера и обособлять ее творчески-практические обусловленности.

Как справедливо отмечает С. Владимиров, когда мы говорим о характере в применении к образу человека в искусстве, то подразуме-

(C) Ван Пен, 2014 
ваем типический характер, но при этом учитываем его связь с живой человеческой индивидуальностью во всем многообразии присущих ей черт и качеств [4].

Цель оперного искусства в его непосредственной сценической данности, достижение которой осуществляется каждой оперной постановкой, заключается в том, чтобы убедительно представить художественно-эстетическую квинтэссенцию образа жизни, следовательно, образа, способа мыслить и чувствовать индивидуальной личности, значительность характера которой обусловлена ее психологической незаурядностью, одновременно показательностью и узнаваемостью. Можно сказать, что в образе оперного персонажа определяющей становится антиномия типичности и исключительности: это либо исключительно яркая личность в типических жизненных обстоятельствах, либо типический человек в исключительном стечении событий, часто приобретающем фатальную направленность.

И то, и другое, будучи воссоздаваемым на оперной сцене и являясь главной предпосылкой в формировании оперного драматически-игрового характера, требует от оперного исполнителя значительного актерского мастерства, владения техникой образного перевоплощения и ролевого сценического поведения. Не случайно ведущие современные оперные исполнители-вокалисты обладают прекрасными внешними данными, в которые входит владение телесной кинетикой, психосемантикой жестикуляции и мимических выражений; вокальное осуществление, буквально - исполнениенаполнение образа, является лишь одним, хотя и ведущим в эстетическом отношении, слагаемым индивидуализированного персонажного оперного образа.

Характерологические свойства оперного образа определяют степень его реалистичности; но оперный характер не является подлинным житейским, а обладает качествами художественной иллюзии, благодаря которой он предстает обобщающим, типизирующим и индивидуализированным в одно и то же время. Драматическая условность оперного характера является необходимым условием его яркости, убедительности, запоминаемости. Ее образуют множественные художественные элементы, в том числе музыкальная выразительность. Но ведущим средством оказывается устойчивость местоположения данного оперного сценического образа по отношению к другим персонажам, этический строй персонажной роли, на основе которой выстраивается индивидуализированная образно-характерологиче- 
ская концепция. О важности данной устойчивости свидетельствуют приводимые С. Владимировым определения характера в античной эстетике, по Аристотелю, в этимологическом искусствоведении, по С. Аверинцеву, в диалогической феноменологии, по М. Бахтину [4].

Так, античная традиция понимала под характером совокупность свойств личности, которые предопределяют постоянство ее поведения в разных ситуациях. В античных представлениях о человеческой характерологии всегда главенствует определенная психологическая черта, становящаяся достаточным показателем личностной экзистенции (болтун и лжец всегда остается таковым, а благородный герой всегда верен своим идеалам и т. д.). Интерпретируя этимологию термина «характер» в его древнегреческом употреблении, С. Аверинцев пишет: «Слово это по исходному смыслу означает либо вырезанную печать, либо вдавленный оттиск этой печати, стало быть, некий резко очерченный и неподвижно застывший пластический облик, который легко без ошибки распознать среди всех других» [1, с. 55]. Такой характер можно наблюдать и исследовать как некую вещь, объективно существующее явление, что, по мнению С. Аверинцева, указывает на «коренную недиалогичность» греческой культуры. Даже о Сократе, исходя из диалогов Платона, исследователь судит как о «радикально недиалогичном человеке», «который в пылу спора остается всецело непроницаемым, неуязвимым, недостижимым для всякого иного «я» $[1$, с. 53$]$.

Однако диалогичность является атрибутивной чертой любого культурного и личностно-психологического феномена, хотя и может проявляться в различных формах и видовых позициях. Наиболее динамичная позиция, приводящая к представлению о смысловой множественности сознания и полифоническом расслоении смысла, исследована в трудах М. Бахтина на основе анализа прозы Ф. Достоевского. Как указывает С. Владимиров, получается, что в романах Достевского вообще нет характеров в аристотелевском понимании, как статических данностей, а ведущей стороной личности оказывается борьба, непрерывность внутренних превращений, несовпадения с самим собой, преодоление судьбы в достижении собственной человечности. Таким образом, дискурсивным путем, опосредованно, проявляется парадоксальная природа человеческого характера, которая последовательно реализовывалась в процессе исторического развития человека и представлений о нем: постоянство, устойчивость и подвижность, изменчивость; статическое и динамическое начала. 
Оба они раскрываются в коммуникативном процессе, то есть диалогическим путем, а вне общения лишены возможности проявления.

Следовательно, диалогичность, включенность в диалогический процесс на различных его уровнях - это этимологическое качество человеческого характера, которое укрупняется, усиливается в случае художественного воспроизведения данного характера. Исходя из этого, характерологическое содержание оперного образа можно определить, исходя из форм и типов диалогического взаимодействия, предполагаемых жанровой формой оперы. Отсюда его системное строение и композиционная развернутость, наряду со структурной определенностью и семантической закрепленностью. Оперный характер познается, оценивается, переживается в отношениях и по отношению к иному типу характера посредством движения через все характерологическое поле оперного произведения.

Встречное движение оперных характеров способствует пониманию каждого из них. Это утверждение можно дополнить мыслью М. Бахтина о предметной ориентации понимания: «Встреча с великим как с чем-то определяющим, обязывающим и связывающим это высший момент понимания» [2, с. 366]. «Встреча» в поэтике Бахтина рассматривается как хронотопичный мотив, который может получать и метафорическое, и символическое применение, выполняет определенные композиционные функции (служит завязкой, иногда кульминацией или развязкой сюжета), приобретает собственные антиномичные субмотивы - обретение - потеря, узнавание - неузнание, но Бахтин придает ему универсальное культурное значение, считая эквивалентом понятия контакта [3, с. 247-248]. Важнее всего то, что обнаруживается «высокая степень эмоционально-ценностной интенсивности» данного хронотопа [3, с. 392].

Вышеизложенное позволяет создать новый контекст для оценки эмоционально-аффективного наполнения характера оперного персонажа, перевести ее на более высокий уровень обобщения и, в частности, позволяет понять причину упоминания Л. Выготским мысли Аристотеля о том, что поэтический (художественный, музыкальный. - B. П.) язык должен звучать как «чужестранный». Объясняя найденный Липпсом эффект «психологической запруды» - соаффекта в трагическом «впечатлении», Выготский так его комментирует: «Я в повышенной степени чувствую себя и свою человеческую ценность в другом (курсив наш. - В. П.), в повышенной степени переживаю, что значит быть человеком...» [5, с. 263]. 
«Сложное превращение чувств», «умная» художественная эмоция, «эмоциональное мышление» раскрываются не как противоречие между позитивной и негативной направленностью образа (в частности, в условиях трагического отношения), а как преодоление обыденных, расхожих житейских способов реагирования «специальными», вызываемыми природой и действием искусства, как диалог «свое» - «чужое», оборачивающийся ответным взаимодействием «чужое» - «свое», «встречей» с собственной отграниченностью, обособленностью, не-свободой, одновременно, со своим правом на выбор, «поступок», «участность» в бытии, причастность к иным границам возможностей. Сказанное подводит к обсуждению проблемы самосознания в работах М. Бахтина, причем исследователь не только ставит вопрос о свободе, достигаемой в самосознании, но и обращает внимание на специфический характер этой свободы - именно как свободы сознания, смысловой, следовательно, истинной, в отличие от свободы бытия, которая является относительной, меняет состав бытия, но не его смысл, не будучи творческой силой, легко может стать насилием: «Совпадает ли сознающий с сознаваемым? Другими словами, остается ли человек только с самим собою, то есть одиноким? Не меняется ли здесь в корне все событие бытия человека? Это действительно так. Здесь появляется нечто абсолютно новое: надчеловек, над-я, то есть свидетель и судья всего человека (всего я), следовательно, уже не человек, уже не $я$, а другой.. Отражение себя в эмпирическом другом, через которого надо пройти, чтобы выйти к я-для-себя (может ли это я-для-себя быть одиноким?). Абсолютная свобода этого $я$. Но эта свобода не может изменить бытие, так сказать материально... - она может изменить только смысл бытия... Истина, правда присуща не самому бытию, а бытию познанному и изреченному...» [2, с. 361].

Особым качеством художественного характера является его осмысленность вследствие встречи с «другим», как подтверждение его «разумности», непосредственно реализуемой в способах поведения и высказывания. По мнению С. Владимирова, «...эта «разумность» или умение поэтически точно изложить, обосновать свою точку зрения является достоянием каждого действующего лица в той степени, в какой ею обладает автор трагедии. Тут от характера ничего не зависит. Не является характером хор, хотя это действующее лищо» [4, с. 85]. Трудно полностью согласиться с данной мыслью, поскольку каждое действующее лицо, даже собирательное, является в сценическом 
представлении выразителем определенного отношения, определенной характерологической позиции.

Характер - психологическая внешность человека и действенная имманентность его внутренней жизни, он воплощает драматургический этос отношений, персонифицирует данный этос, поскольку за каждым характером скрывается человеческая личность, как разумная и «говорящая», то есть способная выражать содержание своего сознания, находить внутреннюю и внешнюю формы данного выражения. Посредством данной личности в драме совокупной человеческой судьбы обозначаются те силы, которые воздействуют на выбор жизненного пути человека, следовательно, определяют художественную логику воспроизведения данного пути в сценической театральной постановке.

Так, в античной трагедии посредством действия и выражения, в том числе хорового, отношения к нему запечатлеваются «роковые» законы бытия. «Но в том-то и особенность драмы, - и мимо этого не проходит Аристотель, - что эти силы не могут предстать сами по себе, они находят выражение все-таки в персонажах, их поступках столкновениях, в перипетиях и развязках судеб. Иными словами, уже Аристотель поставил проблему взаимодействия общего и индивидуального в драматическом характере, хотя понятие «характер» он употреблял совсем в ином, гораздо более ограниченном смысле» $[4$, c. 85].

Разработка оперного характера обусловлена эстетическим модусом оперного произведения. Всегда оставаясь «драмой посредством музыки», опера предполагает основные способы катартического разрешения данной драмы в сложно-диалогическом контексте персонажных отношений, то есть специфическими композиционнодраматургическими средствами. Эти способы можно определять как эпический, трагедийный, комедийно-гротесковый и лирический. Они предъявляют различные семантические приемы достижения катарсиса как заключительного эстетического эффекта.

Так, логика воплощения эпического характера ведет к декларативному типу катарсиса, непосредственно заявленного рядом композиционных приемов; с ней также связан кларитивный тип эстетического «очищения», разъясняющийся путем сопоставления различных групп приемов, впрочем, сохраняющий и элементы декларативности, например, в моменты заключительного утверждения ключевой идеи. 
Трагедийный и комедийный характеры находят свое катартическое оправдания в вуалирующем, отстраненном типе катарсиса, основанном на осознании смыслового единства композиции и значений композиционных приемов (композиционной «игры») после завершения произведения; в этом случае, впрочем, возможно участие и кларитивных композиционных функций.

Лирический характер предполагает элиминирующий способ «очищения», связанный с избеганием привычных ассоциативных путей восприятия образа, зарождающийся «в недрах» предыдущего, достигающий самостоятельности в связи с новым пониманием образной (в том числе - музыкальной) динамики.

Названные типы катарсиса, посредством композиционной логики, соответствуют основным группам диалога, возможным в «персонажном пространстве» оперного произведения. В соответствии с типологией диалога, предложенной М. Бахтиным, укажем, что для «диалога отождествления» и «диалога согласия» характерна декларативная форма катарсиса, для «диалога растождествления» и «диалога разногласия» - кларитивная, для «ностальгического» диалога, «диалога по умолчанию» и «прогностического диалога» - элиминирующая.

Композиционная и эстетическая сложность оперного характера требует солидаризации множества творческих функций современного оперного исполнителя, так сказать, его профессиональной мультиверсийности,

Целесообразно ставить вопрос о межвидовых различиях театрально-драматического и музыкального искусств, выделяя специально специфику музыкальных средств выразительности - музыки как художественного языка, в том числе, привлекая понятия о музыкальном содержании театрального творчества. Обновление в современных режиссерских интерпретациях событийно-драматической модели известных, устойчиво-репертуарных образцов оперного жанра требует, во-первых, активизации психологического подхода к ролевым характерологическим задачам оперного певца, во-вторых, возрастания внимания к некоторым дидактическим вопросам, а именно, о том, каким образом можно научить оперного исполнителя распознавать «драматический нерв» музыкального искусства, развивать собственную актерскую интуицию как ключ к целостному пониманию образного содержания роли, замысла спектакля.

Для современной художественной культуры показательным является процесс жанровой интерференции театрального искусства, то 
есть встречного движения - наложения жанровых форм драматического и музыкального театров, приобретающий особое значение для оперной практики. Граница между драматическим и музыкальным театрами, начиная с момента «возникновения трагедии из духа музыки», всегда была до известной степени условной. Уместно вспомнить здесь и опыт Ж. Б. Люлли, буквально копирующего манеру декламации М. Шанмеле с целью создания национального интонационного строя оперного речитатива, и драматические новации Р. Вагнера, и драматические «колебания» Д. Верди, и процесс становления русской оперы, и мн. другое.

Сегодня наиболее активно взаимодействуют между собой жанровые тенденции театра музыкальной комедии и театра драматического, что вполне объясняется попыткой осовременивания и «осерьезнивания» - тематического возвышения - содержания первого и попыткой демократизации, популяризации содержания второго. Не остаются в стороне кинематограф и телевидение с его омузыкаленными сериалами, в равной степени воздействующие на все виды театральной режиссуры, однако более всего «заражающие» своей технологией и спецэффектами жанры современной оперетты, мюзикла, наконец, оперы.

Новые технологические сценические «контаминации» оказываются в центре внимания оперных режиссеров, поскольку они (режиссеры) ожидают от оперных певцов особого сценического поведения и самовыражения - драматического по своему основному заданию. И вот здесь возникает весьма интересное противоречие: при технологическом сближении музыкального и драматического театров сохраняется существенная профессиональная дистанция между типами актеров данных театральных институций, равно как и между системами их образовательной подготовки. Если драматический театр сегодня должен воспитывать для себя «поющих актеров», то и оперный театр сегодня озабочен формированием «актерствующих певцов», то есть академических оперных вокалистов, способных к убедительной драматической игре и к свободному сценическому поведению, к творческой личностной активности и динамике.

Таким образом, главные трудности театрально-жанрового интерферентного процесса и задачи их преодоления всегда ложатся «на плечи» исполнителей и во многом зависят от их личностных творческих возможностей. Как известно, система К. Станиславского требует постоянной памяти о границе между присущим актеру строем 
чувств, личностных свойств и игровым образом как предметом эмпатии. Однако важнее другое: авторство оперного исполнителя как создателя драматического характера, подкрепленное музыкальной стороной образа, выражается в убедительном представлении возможной новой личности как действительной - действующей и переживающей, соединяющей реальность и иллюзию в сценическом оперном действии.

Так, опорной категорией в разъяснении природы и функций оперного характера становится игра, в том числе бахтинское понятие «игры границ» между автором и образным содержанием произведения, а также такой ряд понятий, как интенциональность, участность (эстетическое бескорыстие), обусловленность. По совокупности обозначенных данными понятиями явлений создание оперного характера становится средством достижения того, что М. Бахтин называл «третьим в диалоге» или «идеальным Над-адресатом», имея в виду смыслополагание или «чувство смысла».

\section{СПИСОК ЛИТЕРАТУРЫ}

1. Аверинцев С. Греческая «литература» и ближневосточная «словесность» (два творческих принципа) / С. С. Аверинцев // Вопросы литературы. -1971 . - № 8. - С. 40-68.

2. Бахтин М. Из записей 1970-1971 годов / М. М. Бахтин // М. М. Бахтин. Эстетика словесного творчества. - М. : Искусство, 1986. - С. 355-380.

3. Бахтин М. Формы времени и хронотопа в романе / М. М. Бахтин // М. М. Бахтин. Вопросы литературы и эстетики. Исследования разных лет. М. : Художественная литература, 1975. - С. 234-407.

4. Владимиров С. В. Действие в драме / С. В. Владимиров. - [2-е изд., доп.]. - СПб. : Издательство СПбГАТИ, 2007. - 192 с.

5. Выготский Л. Психология искусства / Л. С. Выготский. - М. : Искусство, $1968 .-576$ с.

Ван Пен. Драматична умовність оперного характеру у світлі діалогічного nідxоду: до постановки проблеми. У статті розроблюється дефініція драматичного оперного характеру, визначаються драматичні аспекти оперного образу як передумова втілення оперного характеру. Пропонуються діалогічні критерії оцінки сценічної поведінки оперних персонажів, уточнюються різновиди катартичного розв'язання драматичних оперних колізій. Ставиться питання про необхідність драматичного поглиблення професійної майстерності оперних співаків.

Ключові слова: драматичний характер, оперне виконання, діалог, гра, катарсис. 
Wang Peng. To the problem of dramatic conventionalityof opera in the light of the dialogic approach. The article develops a definition of dramatic opera character, determines the dramatic aspects of the image of opera as a prerequisite for realization of the opera character. The dialogical criteria of evaluation of the stage behavior of opera characters are proposed, the varieties of cathartic resolution of the dramatic opera collisions are refined. The question about the need for a dramatic deepening of the professional skills of opera singers is raised.

Keywords: dramatic character, operatic performance, dialogue, game, catharsis.

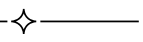

